\title{
ПРИМЕНЕНИЕ БИО- И ДНК-ТЕХНОЛОГИЙ В ННЦ «ИВиВ им. В.Е. Таирова»
}

\author{
Власов В., Мулюкина Нина, Зеленянская Наталия, Гереикий Р. \\ Национальный научный центр «Институт виноградарства и виноделия им. В.Е. \\ Таирова»,Одесса, Украина \\ e-mail: tairmna2005@ukr.net
}

Молекулярно-генетические и биотехнологические исследования в области виноградарства в настоящее время включают изучение в качестве объекта как непосредственно вида Vitis vinifera, так и ряда его патогенов.

Исследования последних трех лет, проводимые в ННЦ «ИВиВ им. В.Е. Таирова», были сосредоточены на основных трех направлениях.

На первом из них совместно с доктором Алешем Эйхмейером (Менделевский университет, Брно, Чехия) при помощи ПЦР и секвенирования ДНК впервые в Украине была проведена диагностика грибных патогенов, ассоциированых с эской винограда.

Для амплификации ITS области использовали праймеры ITS1 и ITS4. Продукты ПЦР, соответствующие размеру около $550 \mathrm{bp}$, секвенировали и полученные нуклеотидные последовательности анализировали с помощью CLC Main Workbench 5.0 (CLC bio, Aarhus, Denmark). Определение видового состава потенциальных возбудителей комплекса эски показало присутствие видов, связанных с болезнями многолетней древесины винограда. При этом было выявлено 3 изолята вида Cadophora luteo-olivacea, которая относится к специфическим патогенам комплекса эски. Образцы, пораженные эской, показали также присутствие вида Eutypa lata (возбудитель отмирания винограда - эутипоза - eutipa dieback) и Botryosphaeria dothidea (возбудитель отмирания - botrioshaeria dieback). При этом ни в одном из образцов не были обнаружены типичные для европейских виноградарских стран виды, ассоциированные с эской - Phaeomoniella chlamydospora, Phaeoacremonium aleophilum, Fomitiporia mediterranea.

Второе направление связано с поиском биохимических маркеров устойчивости к эске и другим грибным болезням многолетней древесины винограда, перспективных для использования в селекции сортов, устойчивых к этим болезням.

На примере сортов винограда селекции ННЦ «ИВиВ им. В.Е. Таирова» было показано, что наличие в геноме технических сортов винограда генетического материала Vitis amurensis и Vitis rupestris увеличивает содержание общих полифенолов в сусле. Продемонстрировано, что разная степень поражения эской коррелирует с уровнями содержания ряда групп полифенолов винограда, в частности, меньшее проявление симптомов соответствует большему количеству полифенольных соединений из групп флавонолов, флаванонов, флавонов, антоцианов и большему суммарному содержанию полифенолов. Анализ отдельных соединений показал, что здоровые (бессимптомные) кусты характеризуются большим содержанием хлорогеновой кислоты, в то время как в кустах с симптомами эски повышено содержание кверцетина, нарингенина и лютеолина. Выявленные зависимости могут стать основой для разработки метода ранней диагностики устойчивости винограда к грибным болезням в процессе селекции.

Третье направление исследований представлено разработкой методов ускоренного скрининга подвойных сортов винограда при помощи разработанных в отделе размножения питательных сред для оценки на соле- и засухоустойчивость в культуре in vitro. 